\title{
Research on Key Influencing Factors of Undergraduates' Cultivating Performances Based on TTF Theory
}

\author{
Hao $\mathrm{Wu}$ \\ College of Economics and Management \\ China Jiliang University \\ Hangzhou, China \\ 464683143@qq.com
}

\author{
Wanli Ma* \\ College of Economics and Management \\ China Jiliang University \\ Hangzhou, China \\ mawl@cjlu.edu.cn
}

\begin{abstract}
Based on TTF theory, this paper analyzes the intrinsic relationship between the learning characteristics of undergraduates, the characteristics of university training, the fit of the former two and the cultivating performance of undergraduates, constructs the model of undergraduates' cultivating performance mechanism. The empirical results of the field investigation of China Jiliang University show that the matching of the students' learning characteristics and the university training characteristics have a significant positive impact on the undergraduates' cultivating performance; and the students' learning characteristics are mainly marked by students' innovation, learning attitude, knowledge level, learning/perception ability; moreover, teachers are the most critical influencing factors in university training. The research results enrich the theory of undergraduates' cultivating performances.
\end{abstract}

Keywords-Undergraduates, Cultivating Performances, Influencing Factors, Task-Technology Fit Model, Structural Equation Modeling

\section{INTRODUCTION}

The quality of undergraduates' cultivating education is directly related to the country's economic construction and development in the future, improving the cultivating performance of undergraduates is the focal point of China's current and future development of higher education. At present, there are a great number of documents dealing with the research of undergraduates' cultivating performance. However, the researches on the key influencing factors of undergraduates' cultivating performance and it's mechanism from the perspective of the fit of the characteristics of students' learning and the characteristics of university training are still rare. Taking the China Jiliang University as the research sample, the influencing factors of undergraduates' cultivating performance as the start point, and based on the theory of TTF, this paper constructs the model of undergraduates' cultivating performance mechanism, and analyzes the key influencing factors and the mechanism of the undergraduates' cultivating performance, to provide experiences and references for promoting undergraduates' cultivating performance of various colleges and universities.

\section{TheORETICAL BASIS AND RESEARCH MODEL}

The theoretical basis of this paper is the Task-Technology Fit (TTF) theory proposed by Goodhue and Thompson in 1995. The theory argues the phenomenon that the higher the matching degree between "technical characteristics" and "task characteristics", the more users are willing to use the technology shows the ability of information technology to support the task work [1]. Gooodhue et al. (2000) also demonstrated that TTF would affect the performance and that TTF, which is a latent variable, could be successfully evaluated by the users [2]. In view of this, this paper argues that the fit of undergraduates' learning characteristics and university training characteristics will affect the cultivating performance of undergraduates. As shown in Fig. 1.

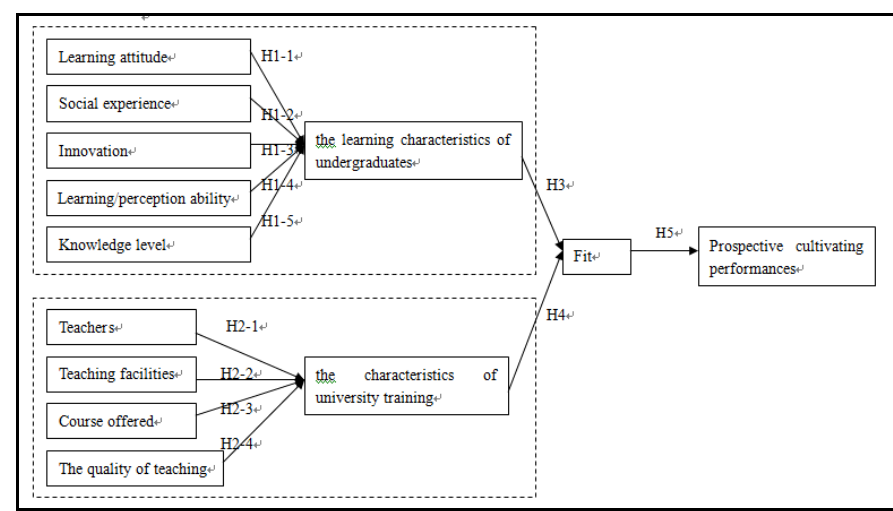

Fig. 1. Cultivating Fit Model

In the above figure, through the study of related documents, it is found that the learning characteristics of students are composed of five aspects: learning attitude, practical experience, innovation, learning/perception ability and knowledge level[3-5]; while the university training characteristics are composed of the following four aspects: teachers, teaching facilities, curriculum design, and the quality of teaching[4-6].

\section{RESEARCH HYPOTHESIS}

According to Goodhue \& Thompson (1995) and Goodhue (1995) research which showed that both technology 
characteristic and task features would directly influence the task and technology [1], and the interaction between the task and technology will affect technical compatibility. Performance can be good only when technology was used and it has good matching with task characteristics [7]. In view of the above, the following hypotheses come up:

H3: The students' learning characteristics have a positive effect for the matching degree between the students' learning characteristics and university training characteristics;

H4: University training characteristics have a positive effect for the matching degree between the students' learning characteristic and university training characteristics;

High matching degrees between the students' learning characteristic and university training characteristics mean university training can satisfy the needs of the students, so that it can produce better cultivating performances results. Staples and Seddon (2004) argued that matching degrees could make the technology to have consistent results with task requirements, and the results are a kind of expression of usefulness [8]. The thesis statement has been proved by the empirical study. Accordingly, the following hypothesis comes up:

H5: The matching degrees between the students' learning characteristics and the university training characteristics have a positive effect for the prospective cultivating performances.

According to the result including the identification of factors for the students' learning factors characteristics [3-5] and the identification of factors for the university training characteristics [4-6], the paper has following hypotheses:

H1-1: The students' learning attitude has a positive effect on the students' learning characteristics;

H1-2: The students' social experience has a positive effect on the students' learning characteristics;

H1-3: The innovation ability of students has a positive effect on the students' learning characteristics;

H1-4: The learning ability of students has a positive effect on the students' learning characteristics;

H1-5: The students' knowledge level has a positive effect on the students' learning characteristics;

H2-1: The university teachers have positive effects on the university training characteristics;

H2-2: The university teaching facilities have a positive effect on the university training characteristics;

H2-3: The university curriculum design has a positive effect on the university training characteristics;

H2-4: The university quality of teaching has a positive effect on the university training characteristics.

\section{EMPIRICAL RESEARCH}

\section{A. Observing Variables and Questionnaire Design}

"Learning attitude" and "social experience", which are the observation variables of the learning characteristics of students, were adapted from Wilkinson, Roberts, While(2010); while "innovation" and "knowledge level” were adapted from Thong \& Yap(1995); along with the "learning /perception ability" adapted from Kuan \& Chau(2001). When it comes to the observation variables of university training characteristics, the "teacher" was adapted from Stephan Poehnans (2015); and the following three observation variables "teaching facilities", "curriculum design" and "teaching quality” were adapted from Yang Deyun (2013); "matching” was adapted from Chang (2010); and "prospective cultivating performances" was adapted from Wixom \& Todd (2005), etc. Before the formal investigation, 20 experts were invited to participate in the pretest, and modified the wording, length, and format of the questions raised by the experts in the questionnaire. And finally, based on the results of the pretest, 43 questions were introduced and formed a questionnaire; the variables were measured by the 7-point Likert scale.

\section{B. Data Collection and Statistical Analysis s}

160 questionnaires were issued to the undergraduates of China Jiliang University. Excluding unqualified questionnaires and there were still 146 valid questionnaires. The recovery rate was $97 \%$. It can be seen from the basic situation of the students surveyed that the sample contains different sexes, grades, native places and majors which, showed a strong randomness, ensured the reliability of the conclusion.

\section{1) Sample Statistics}

The basic characteristics of the effective samples of this survey involve gender, professional category, grade, family location and, etc. In terms of gender, girls, accounted for $53 \%$ of the total surveyed people, are more than boys; when it comes to professional category, $76 \%$ of the students major in economics and management; in view of the family location, students who come from the townships and rural areas are slightly more than those who come from cities.

\section{2) Reliability and Validity Tests}

Reliability and validity tests, the load-factors of all the questions should be more than 0.65 , which is basically in line with Fornell \& Larcker recommendations. Cronbach's $\alpha$ is between 0.71 and 0.93, which is in line with Hair's recommendations. The composite reliability (CR) ranged from 0.827 to 0.948 with an average variation extraction (AVE) of 0.6 to 0.9 , which is in line with Nunnally \& Bernstein's recommendations. Therefore, the data of this study are consistent with reliability and convergent validity, as shown in Table I . The square root of the average variance extraction (AVE) of each facet is larger than the correlation coefficient between each facet, so the data of this study are in accordance with the discriminate validity, as shown in Table II .

\section{Structural Equation Analysis}

In the view of formative facets from the first class to the second class, the learning attitude, social experience, innovation, learning / perception ability and knowledge level all have a positive impact on the learning characteristics of the students who belong to the second class, so the results of this study support hypothesis H11, H1-2, H1-3, H1-4, and H1-5.

The teachers, teaching facilities, curriculum design and 
teaching quality of the first class have a positive effect on all the university training characteristics of the second class; therefore, the results of this study support the following hypothesis: H2-1, H2-2, H2-3, and H2-4.

TABLE I. RELIABILITY ANALYSIS

\begin{tabular}{|c|c|c|c|c|c|}
\hline Latent variable & Number of observed variables & $\begin{array}{c}\text { Observed variables } \\
\text { LATT- } 1\end{array}$ & $\begin{array}{c}\text { Factor load } \\
0.842\end{array}$ & Reliability coefficient $\alpha$ & $\mathbf{C R}$ \\
\hline \multirow[t]{2}{*}{ Learning attitude } & \multirow[t]{2}{*}{4} & $\begin{array}{l}\text { LATT-2 } \\
\text { LATT-3 }\end{array}$ & $\begin{array}{l}0.831 \\
0.751\end{array}$ & \multirow[t]{2}{*}{0.771} & \multirow[t]{2}{*}{0.855} \\
\hline & & LATT- 4 & 0.653 & & \\
\hline \multirow[t]{2}{*}{ Social experience } & \multirow[t]{2}{*}{2} & $\begin{array}{l}\text { SE-1 } \\
\text { SE-2 }\end{array}$ & $\begin{array}{l}0.846 \\
0.911\end{array}$ & \multirow[t]{2}{*}{0.710} & \multirow[t]{2}{*}{0.872} \\
\hline & & INNO-1 & 0.745 & & \\
\hline \multirow[t]{2}{*}{ Innovation } & \multirow[t]{2}{*}{4} & $\begin{array}{l}\text { INNO-2 } \\
\text { INNO-3 }\end{array}$ & $\begin{array}{l}0.660 \\
0.757\end{array}$ & \multirow[t]{2}{*}{0.724} & \multirow[t]{2}{*}{0.827} \\
\hline & & INNO-4 & 0.787 & & \\
\hline \multirow[t]{2}{*}{ Learning/Perception ability } & \multirow[t]{2}{*}{2} & $\begin{array}{l}\text { LPA-1 } \\
\text { LPA-2 }\end{array}$ & $\begin{array}{l}0.924 \\
0.923\end{array}$ & \multirow[t]{2}{*}{0.827} & \multirow[t]{2}{*}{0.921} \\
\hline & & KNOW-1 & 0.916 & & \\
\hline \multirow[t]{3}{*}{ Knowledge level } & \multirow[t]{3}{*}{3} & KNOW-2 & 0.916 & \multirow[t]{3}{*}{0.857} & \multirow[t]{3}{*}{0.913} \\
\hline & & KNOW-3 & 0.810 & & \\
\hline & & TEA-1 & 0.708 & & \\
\hline \multirow{2}{*}{ Teachers } & \multirow{2}{*}{4} & TEA-2 & 0.858 & \multirow{2}{*}{0.819} & \multirow{2}{*}{0.881} \\
\hline & & $\begin{array}{l}\text { TEA-3 } \\
\text { TEA-4 }\end{array}$ & $\begin{array}{l}0.844 \\
0.808\end{array}$ & & \\
\hline \multirow{2}{*}{ Teaching facilities } & \multirow{2}{*}{2} & TF-1 & 0.928 & \multirow{2}{*}{0.851} & \multirow{2}{*}{0.931} \\
\hline & & TF-2 & 0.938 & & \\
\hline Curriculum design & 2 & CD-1 & 0.950 & 0.889 & 0.948 \\
\hline & & CD-2 & 0.947 & & \\
\hline Quality of teaching & 2 & $\begin{array}{l}\text { QT-1 } \\
\text { QT-2 }\end{array}$ & 0.921 & 0.800 & 0.909 \\
\hline & & FIT-1 & 0.649 & & \\
\hline & & FIT-2 & 0.766 & & \\
\hline & & FIT-3 & 0.716 & & \\
\hline & & FIT-4 & 0.719 & 0.856 & \\
\hline Fit & 8 & FIT-5 & 0.683 & 0.856 & 0.888 \\
\hline & & FIT-6 & 0.679 & & \\
\hline & & FIT-7 & 0.726 & & \\
\hline & & FIT-8 & 0.707 & & \\
\hline & & $\mathrm{P}-1$ & 0.757 & & \\
\hline & & $\mathrm{P}-2$ & 0.791 & & \\
\hline & & P-3 & 0.831 & & \\
\hline & & P-4 & 0.844 & & \\
\hline Prospective cultivating performances & 10 & P-5 & 0.722 & 0.926 & 0.938 \\
\hline & & P-6 & 0.810 & & \\
\hline & & P-7 & 0.799 & & \\
\hline & & P-8 & 0.743 & & \\
\hline & & P-9 & 0.808 & & \\
\hline & & P-10 & 0.641 & & \\
\hline
\end{tabular}

TABLE II. CORRELATION MATRIX

\begin{tabular}{|c|c|c|c|c|c|c|c|c|c|c|c|}
\hline & $\begin{array}{l}\text { Learning } \\
\text { attitude }\end{array}$ & $\begin{array}{c}\text { Social } \\
\text { experience }\end{array}$ & Innovation & $\begin{array}{l}\text { Learning/ } \\
\text { Perception } \\
\text { ability }\end{array}$ & $\begin{array}{c}\text { Knowledge } \\
\text { level }\end{array}$ & Teachers & $\begin{array}{l}\text { Teaching } \\
\text { facilities }\end{array}$ & $\begin{array}{l}\text { Curriculum } \\
\text { design }\end{array}$ & $\begin{array}{l}\text { Quality } \\
\text { of } \\
\text { teaching }\end{array}$ & Fit & $\begin{array}{c}\text { Prospective } \\
\text { cultivating } \\
\text { performances }\end{array}$ \\
\hline $\begin{array}{l}\text { Learning } \\
\text { attitude }\end{array}$ & 0.773 & & & & & & & & & & \\
\hline $\begin{array}{c}\text { Social } \\
\text { experience }\end{array}$ & 0.471 & 0.879 & & & & & & & & & \\
\hline Innovation & 0.448 & 0.530 & 0.743 & & & & & & & & \\
\hline $\begin{array}{l}\text { Learning/ } \\
\text { Perception } \\
\text { ability }\end{array}$ & 0.448 & 0.412 & 0.739 & 0.923 & & & & & & & \\
\hline $\begin{array}{c}\text { Knowledge } \\
\text { level }\end{array}$ & 0.126 & 0.302 & 0.488 & 0.538 & 0.882 & & & & & & \\
\hline Teachers & 0.388 & 0.204 & 0.266 & 0.305 & 0.307 & 0.807 & & & & & \\
\hline $\begin{array}{l}\text { Teaching } \\
\text { facilities }\end{array}$ & 0.345 & 0.195 & 0.194 & 0.189 & 0.108 & 0.504 & 0.933 & & & & \\
\hline $\begin{array}{l}\text { Curriculum } \\
\text { design }\end{array}$ & 0.486 & 0.180 & 0.277 & 0.247 & 0.063 & 0.471 & 0.686 & 0.949 & & & \\
\hline $\begin{array}{c}\text { Quality of } \\
\text { teaching }\end{array}$ & 0.379 & 0.151 & 0.321 & 0.295 & 0.202 & 0.543 & 0.562 & 0.706 & 0.913 & & \\
\hline Fit & 0.472 & 0.472 & 0.459 & 0.498 & 0.467 & 0.588 & 0.349 & 0.407 & 0.584 & 0.760 & \\
\hline $\begin{array}{l}\text { Prospective } \\
\text { cultivating } \\
\text { performances }\end{array}$ & 0.489 & 0.473 & 0.557 & 0.560 & 0.337 & 0.519 & 0.430 & 0.468 & 0.687 & 0.706 & 0.776 \\
\hline
\end{tabular}

Then this study will analyze the relationship between the dimensions of the second class. Assuming the learning characteristics of H3, H4 students and the university training characteristics have a positive effect on matching, then it can 
be concluded that the results of this study support hypothesis $\mathrm{H} 3$ and $\mathrm{H} 4$.

Assuming that the matching of $\mathrm{H} 5$ has a positive effect on the expected cultivating performance, then it can be concluded that the results of this study support the hypothesis H5.

The hypothesis and validations of the matching model are shown in TableIII.

TABLE III. The Hypothesis VerificAtion OF MATCHING MOdEL

\begin{tabular}{|c|c|c|c|c|}
\hline Hypotheses & Path & $\begin{array}{c}\text { Path } \\
\text { coefficient }\end{array}$ & $\mathbf{T}$ & Result \\
\hline H1-1 & $\begin{array}{l}\text { Learning attitude } \rightarrow \text { the learning } \\
\text { characteristics of students }\end{array}$ & $0.289 * * *$ & 6.833 & Support \\
\hline H1-2 & $\begin{array}{l}\text { Social experience } \rightarrow \text { the learning } \\
\text { characteristics of students }\end{array}$ & $0.194 * * *$ & 11.461 & Support \\
\hline H1-3 & $\begin{array}{c}\text { Innovation } \rightarrow \text { the learning characteristics } \\
\text { of students }\end{array}$ & $0.309 * * *$ & 12.991 & Support \\
\hline $\mathrm{H} 1-4$ & $\begin{array}{l}\text { Learning/Perception ability } \rightarrow \text { the } \\
\text { learning characteristics of students }\end{array}$ & $0.261^{* * *}$ & 9.379 & Support \\
\hline H1-5 & $\begin{array}{l}\text { Knowledge level } \rightarrow \text { the learning } \\
\text { characteristics of students }\end{array}$ & $0.276^{* * *}$ & 3.142 & Support \\
\hline H2-1 & $\begin{array}{c}\text { Teachers } \rightarrow \text { the learning characteristics of } \\
\text { university training }\end{array}$ & $0.429 * * *$ & 11.849 & Support \\
\hline H2-2 & $\begin{array}{l}\text { Teaching facilities } \rightarrow \text { the learning } \\
\text { characteristics of university training }\end{array}$ & $0.243^{* * *}$ & 14.180 & Support \\
\hline H2-3 & $\begin{array}{l}\text { Curriculum design } \rightarrow \text { the learning } \\
\text { characteristics of university training }\end{array}$ & $0.269 * * *$ & 16.503 & Support \\
\hline $\mathrm{H} 2-4$ & $\begin{array}{l}\text { Quality of teaching } \rightarrow \text { the learning } \\
\text { characteristics of university training }\end{array}$ & $0.274 * * *$ & 12.735 & Support \\
\hline H3 & $\begin{array}{l}\text { The learning characteristics of students } \rightarrow \\
\text { fit }\end{array}$ & $0.456 * *$ & 3.026 & Support \\
\hline $\mathrm{H} 4$ & $\begin{array}{l}\text { The learning characteristics of university } \\
\text { training } \rightarrow \text { fit }\end{array}$ & $0.410^{*}$ & 2.077 & Support \\
\hline H5 & $\begin{array}{c}\text { Fit } \rightarrow \text { Prospective cultivating } \\
\text { performances }\end{array}$ & $0.760 * * *$ & 21.011 & Support \\
\hline ps: When & $\begin{array}{l}\mathrm{T}>1.96, " * \text { " expresses } \mathrm{P}<0.25 \text {; When } \mathrm{T}>2 \text {. } \\
\mathrm{T}>3.29 \text {,"***" expresses } \mathrm{P}<0.001 ; \mathrm{n} / \mathrm{s} \text { expres }\end{array}$ & $58, " * * " \mathrm{ex}$ & $\begin{array}{l}\text { sses } \mathrm{P}< \\
\text { icant. }\end{array}$ & .01; When \\
\hline
\end{tabular}

\section{RESEARCH CONCLUSIONS AND SUGGESTIONS}

\section{A. Research Conclusions}

(1) The assumptions presented in this paper are all validated. The key factors influencing the cultivating performance of undergraduates can be divided into two parts: students and universities. When it comes to students, the key factors are mainly innovation, learning attitude, knowledge level, and learning/perception ability; but when it comes to universities, teachers are the most major influencing factors.

(2)The assumptions presented in this paper are all validated. The key factors influencing the cultivating performance of undergraduates can be divided into two parts: students and universities. When it comes to students, the key factors are mainly innovation, learning attitude, knowledge level, and learning/perception ability; but when it comes to universities, teachers are the most major influencing factors.

\section{B. Suggestion}

The following suggestions are made based on the above research conclusions:

(1) In the cultivation of undergraduates, universities and teachers are the key factors. Therefore, to enhance the cultivating performance of undergraduates, it is necessary to strengthen the construction of teaching staff, enhance the teachers' teaching level, clear the responsibilities and division of teachers, and firmly establish the centrality of cultivating undergraduates. At the same time, the universities should also improve the teaching system, equipped with sound teaching equipment, and optimize the professional courses.

(2) The universities should actively cultivate students' sense of innovation, and constantly improve students' learning ability and knowledge level to further improve the students' employment competitiveness.

(3) The universities should design their training programs aiming at students' situation and social needs, and equipped the students' with proper teaching facilities and instructors. The universities should also improve the quality of teaching to improve students' cultivating performance.

\section{LIMITATION AND FORECAST}

(1) Limitations of the research sample. Due to the limited research conditions, there are only few samples in the paper, and they mainly come from China Jiliang University, so the universality of the research conclusion is limited.

(2) Limitations of research content. This study focuses only on the impacts of the matching of the learning characteristics of students and the university training characteristics on the undergraduates' cultivating performance. There are still many problems in improving the undergraduates' cultivating performance waiting for us to explore.

\section{REFERENCES}

[1] Goodhue D L, Thompson R L. Task-technology fit and individual performance [J]. MIS Quarterly, 1995, 19(2):213-236.

[2] Gattiker T F, Goodhue D L. Understanding the Plant Level Costs and Benefits of ERP: Will the Ugly Duckling Always Turn into a Swan?[C]// Hawaii International Conference on System Sciences. IEEE, 2000:10 pp. vol.1.

[3] Zhang Fan. The research about the influence of undergraduates' learning attitude on learning effect [D]. Xi'an Technological University, 2014. (In Chinese)

[4] Luo Wenbiao. Research on the cultivation of enterprise technological innovation talents based on Knowledge Innovation [D]. Jinan University,2006. (In Chinese)

[5] Sang Cuicui, Duan Xinwen, Zhao Jianfei, Zhang Yue. Innovation of university teaching methods and improvement of higher education quality [J]. Qiuzhidaokan, 2016, 49: 118. (In Chinese)

[6] Zhang Hua. A study on the influence of college teaching service quality on students' satisfaction [D]. Qiingdao University, 2012. (In Chinese)

[7] Goodhue D L. Understanding user evaluations of information systems [J].Management Science, 1995, 41(12):1827-1844.

[8] Staples D S, Seddon P. Testing the technology-to-performance [J].Journal of organizational and End User Computing, 2004,16(4):17-36. 